\title{
Screening of Paddy (Oryza sativa L.) Genotypes for Zinc Efficiency under Different Moisture and Salt Stress Condition in Semi-Arid Vertisols
}

\author{
M. Prabhavathi ${ }^{1 *}$, Hrittick Biswas ${ }^{1}$ and N. Chandra Sekharan ${ }^{2}$ \\ ${ }^{1}$ ICAR-Indian Institute of Soil and Water Conservation, Research Centre, \\ Ballari, Karnataka, India \\ ${ }^{2}$ Department of Soil Science and Agricultural Chemistry, TNAU, Coimbatore, \\ Tamil Nadu, India \\ *Corresponding author
}

\begin{abstract}
A B S T R A C T
A pot culture experiment was conducted at ICAR-IISWC, Ballari, Karnataka during 2016 to screen seven paddy genotypes receiving zinc fertilization for their zinc use efficiency

Keywords

Plant height, Chlorophyll content index, TRY 3 , Grain yield, Zinc use efficiency

Article Info

Accepted:

12 February 2019

Available Online:

10 March 2019 under various moisture regimes. The experiment was laid out in a completely randomized design with two replications. At 30 days after transplanting (DAT), the plant height in M2 treatment (Saturated Soil Culture) was higher which was at par with the continuous flooding (M1) and was significantly different with the Alternate Wetting and Drying (M3). The genotype NLR 34449 produced significantly taller plants $(23.8 \mathrm{~cm})$ as compared to GGV $0501(19.1 \mathrm{~cm})$, which was at par with rest of the paddy genotypes. No significant differences in chlorophyll content index (CCI) were observed among different moisture regimes at vegetative stage. But, M1 and M3 treatment induced higher CCI values at tillering and panicle initiation stage, respectively. The AWD resulted in the lowest grain yield while SSC recorded the highest grain yield that was at par with the continuous flooding. Among seven salt tolerant paddy genotypes, TRY 3 was the most efficient, whereas rests of the genotypes were classified as moderately efficient. The results therefore suggested that maintaining rice plants at a saturated condition throughout the growing period helps to attain significant increase in the grain yield besides saving water under water scarce environment.
\end{abstract}

\section{Introduction}

The world's population is estimated to increase from 6 billion to about 10 billion by 2050. To meet the food demand of the teeming billions, a large increase in food production is required. It has been estimated that annual cereal production needs to increase by $40 \%$, from 1773 billon tonnes in 1993 to nearly 2500 billion tonnes in 2020 (Frossard et al., 2000). Besides increase in food production, dietary intake of essential elements/nutrients through food is equally important. For example, zinc ( $\mathrm{Zn}$ ) has been identified as one of the most vital micronutrients for activity of various enzymes 
and proper growth and development of plants, animals and humans (Singh, 2009) and as a possible solution for combating malnutrition (Horton et al., 2009). Worldwide, about 0.8 million people die every year from diseases of zinc deficiency (www.http://crops.zinc.org/ why-zinc/), of which 0.45 million are children below five years (Walker et al., 2009). High consumption of cereal based foods with low levels and poor bioavailability of $\mathrm{Zn}$ is thought to be a major factor for the widespread occurrence of $\mathrm{Zn}$ deficiency in human beings (San, 2006). It is therefore, essential to identify the zinc-deficient areas, assess the causes of deficiency, and plan external zinc fertilization.

About $50 \%$ of the cereal-cultivated soils globally are deficient in plant available $\mathrm{Zn}$, leading to both reductions in crop production and nutritional quality of the harvested grains (Graham et al., 1992; Cakmak, 2008). Further, analysis of over 2,56,000 soil samples from all over India indicated that about $50 \%$ of the soils were deficient in zinc and that this was the most prevalent micronutrient limiting crop yields in India (Singh, 2009).

Submerged soils are well recognized for poor zinc availability to the plants due to reaction of zinc with free sulphide (Mikkelsen and Shiou, 1977). Flooding and submergence bring about a decline in available zinc due to $\mathrm{pH}$ changes and the formation of insoluble zinc compounds. The soil $\mathrm{pH}$ rises with the onset of reducing (gleying) conditions and zinc solubility declines 100 times for each unit increase in $\mathrm{pH}$ (Lindsay, 1972). The insoluble zinc compounds formed are likely to be with $\mathrm{Mn}$ and Fe hydroxides from the breakdown of oxides and adsorption on carbonate, especially magnesium carbonate. Under the submerged conditions of rice cultivation, zinc (either native or applied) is changed into amorphous sesquioxide precipitates or franklinite; $\mathrm{ZnFe}_{2} \mathrm{O}_{4}$ (Sajwan and Lindsay 1988). In rice production, when $\mathrm{Zn}$ is in short supply, yields are often reduced and $\mathrm{Zn}$ concentration in the grains is low. This may result in $\mathrm{Zn}$ malnutrition of people who depend on a rice based diet. Micronutrient malnutrition often called "hidden hunger" has been estimated to afflict over two billion people, especially resource poor woman and children in the developing world and their numbers are increasing (Hambidge, 2000, Von Broun et al., 2005). Crop products constitute the primary source of all micronutrients for humans especially in developing countries. However, the $\mathrm{Zn}$ concentration in cereals may be increased by applying $\mathrm{Zn}$ fertilizer to the soil or directly to the plants (Broadley et al., 2007). Crop species markedly differ in their ability to adapt to $\mathrm{Zn}$ deficient soils (Graham, 1984). Among the cereal species, paddy, sorghum and corn are classified as $\mathrm{Zn}$ deficiency sensitive, whereas, barley, wheat and rye are classified as less sensitive (Clark, 1990). Besides the application of $\mathrm{Zn}$ fertilizers for alleviating $\mathrm{Zn}$ deficiency in animals and humans, a more efficient and sustainable solution is the development and use of $\mathrm{Zn}$ efficient plant genotypes that can more effectively function under low soil $\mathrm{Zn}$ conditions, which would reduce fertilizer inputs and protect the environment as well. With this background, a study was conducted to identify and recommend high zinc-efficient paddy genotypes under different water saving irrigation practices and zinc fertilization levels for zinc-deficient saline soils of semi-arid tropics.

\section{Materials and Methods}

The experiment was laid out in a completely randomized design (CRD) with two replications. Ten $\mathrm{kg}$ of air dried soil was placed in plastic pots. The treatments consisted of three water regimes viz., continuous flooding (CF), saturated soil culture (SSC) and alternate wetting and drying 
(AWD), seven salt tolerant rice genotypes (CSR 22, GGV 0501, NLR 34449, MTU 1010, CO 43, TRY 1 and TRY 3), and three Zn levels viz. control, $37.5 \mathrm{~kg} \mathrm{Zn}$ and $50.0 \mathrm{~kg} \mathrm{ha}^{-1}$ applied through zinc sulphate, and three $\mathrm{N}$ levels viz., control, $125 \mathrm{~kg}$ and $150 \mathrm{~kg} \mathrm{~N} \mathrm{ha-}$ ${ }^{1}$ through urea. Before imposition of zinc treatments, the soils used in the experiment exhibited the following properties viz., $\mathrm{pH}$ 8.3, EC-7.0 dS m${ }^{-1}$, organic carbon- $3.6 \mathrm{~g} \mathrm{~kg}^{-1}$, $\mathrm{KMnO}_{4}-\mathrm{N}-245 \mathrm{~kg} \mathrm{ha}^{-1}$, Olsen-P- $23.2 \mathrm{~kg} \mathrm{ha}^{-1}$, $\mathrm{NH}_{4} \mathrm{OAc}-\mathrm{K}-419 \mathrm{~kg} \mathrm{ha}^{-1}$, Ca- $8.88 \mathrm{meq}$ per $100 \mathrm{~g}, \mathrm{Mg}-1.82$ meq per 100g, DTPA-Zn$0.42 \mathrm{ppm}$, DTPA-Cu- $0.96 \mathrm{ppm}$, DTPA- Fe8.93 ppm, DTPA- Mn- 8.13 ppm, ESP- 64.8 $\%$, SAR- 39.8, and CEC 49.1 meq per $100 \mathrm{~g}$ soil.

Water saving irrigation practices viz., M2 and M3 were followed from 10 days after transplanting to maturity. In SSC regime, pots were irrigated to $1 \mathrm{~cm}$ of ponded water depth a day after the disappearance of water whereas in AWD regime, pots were irrigated at 5 days interval. The same practices were repeated except during flowering, when the pot as maintained with flooded water at a depth of 5 $\mathrm{cm}$. In addition to $\mathrm{Zn}$ treatments, recommended levels of nitrogen were applied as urea, phosphorous, as single super phosphate, and potassium, as $\mathrm{KCl}$ at the time of transplanting. Plant height and chlorophyll content index were measured at regular intervals. A chlorophyll content meter (model OPTI-SCIENCES CCM-200, USA) was used to determine leaf chlorophyll content. Crop was harvested at maturity and grain yields were recorded.

\section{Classification of genotypes according to zinc-use efficiency}

Zn-use efficiency index (ZnUEI) was calculated with the values of grain yield at low and high $\mathrm{Zn}$ levels. The genotypes that produced ZnUEI greater than 1.0 were classified as efficient, while those that produced ZnUEI between 0.50 and 1.0 were classified as moderately efficient, and genotypes with ZnUEI less than 0.50 were classified as inefficient. This index is commonly used in separating nutrient-efficient and nutrient-inefficient crop species or genotypes within species (Fageria, 2009). The $\mathrm{Zn}$ efficiency was calculated by using the following equation.

\section{$\mathrm{ZnUEI}=\mathrm{X} / \mathrm{X}_{1} * \mathrm{Y} / \mathrm{Y}_{1}$}

where,

$\mathrm{X}=$ grain yield of genotype at low $\mathrm{Zn}$ level

$X_{1}=$ average grain yield of 7 genotypes at low $\mathrm{Zn}$ level

$\mathrm{Y}=$ grain yield of genotype at high $\mathrm{Zn}$ level

$\mathrm{Y}_{1}=$ average grain yield of 7 genotype at high $\mathrm{Zn}$ level

The data recorded on various observations during the course of the investigation were analyzed statistically by adopting the procedure described by Panse and Sukhatme (1985). The data were subjected to Fisher's method of analysis of variance and the level of significance used in $\mathrm{F}$ tests was $\mathrm{P}=0.05$. The critical differences were calculated at 5 per cent probability level whenever $\mathrm{F}$ value was found to be significant.

\section{Results and Discussion}

\section{Plant height}

The data in Table 1 reveals that plant height ranged from $14.2 \mathrm{~cm}$ to $27.2 \mathrm{~cm}$ across various moisture regimes. The genotype NLR 34449 produced significantly taller plants $(23.8 \mathrm{~cm})$ as compared to GGV0501 $(19.1 \mathrm{~cm})$, which was at par with rest of paddy genotypes. However, the interaction between the moisture regimes and genotypes was not significant in respect of plant height at two different periods. Further, it is evident from the table 1 that the 
effect of moisture on plant height was significant at $1 \%$ level of probability. Application of water saving irrigation (M2), recorded the maximum plant height of $23.6 \mathrm{~cm}$ at 7 DAT, which was significantly higher than the treatment M3 (AWD) with $20.3 \mathrm{~cm}$ height. The lowest plant height of $18.4 \mathrm{~cm}$ was recorded in M1 (submergence) that was statistically at par with the treatment M3. Similarly, at 30 DAT, the plant height of M2 (SSC) was higher and at par with the submergence (M1), and significantly different from AWD (M3). Water stress at 30 DAT reduced plant height in AWD treatment. According to Zeigler et al., (1994), paddy is extremely sensitive to water shortage and that the growth of plant and size of various plant parts decrease with water shortage below saturated soil moisture content. These results are in line with the assertion by De Datta (1981) that application of water at higher regimes promoted growth of rice by increasing plant height. The difference could be attributed to the fact that field capacity was highly water deficient and therefore was expending more energy to extract water in the soil moisture tension range of $10-15 \mathrm{KPa}$. Figure 1 shows that plant height $(41.7 \mathrm{~cm})$ was increased by $12 \%$ at SSC treatment as compared to AWD whereas no significant difference was observed in continuous flooding.

\section{Chlorophyll content index}

Among the seven paddy genotypes, MTU 1010 recorded the highest chlorophyll content index (CCI) values at vegetative stage (Table 2). The genotypes TRY 1 and TRY 3 produced more CCI at tillering and panicle initiation stage, respectively. No significant differences in chlorophyll content index (CCI) were observed among different moisture regimes at vegetative stage. However, M1 and M3 treatments exhibited significantly higher CCI values at tillering and panicle initiation stage, respectively Leaf chlorophyll content varied according to irrigation regimes and growth stages. At heading stage, the CCI was lowest under $\mathrm{CF}$ which was significantly lower as compared to SSC and AWD moisture regimes (Fig. 1). The results are in agreement with that of Haung et al., (2008) and Zhang et al., (2009), who reported that compared with continuous flooding, intermittent irrigation reduced the leaf transpiration rate and enhanced the leaf photosynthetic rate. Chlorophyll, net photosynthetic rate (Pn), stomatal conductance and transpiration rate decreased in plants under AWD treatment than continuous flooding (Khairi et al., 2015).

Application of zinc did not significantly influence the CCI values up to tillering stage (Fig. 1). But, at later stages, significant difference in CCI value was observed in addition of $\mathrm{Zn}$ application @ $22 \mathrm{mg} \mathrm{kg}^{-1}$ soil.

\section{Grain yield}

From table 3, it could be inferred that grain yield was highest under the treatment M2 (SSC), which was significantly different than the at-par treatments M1 and M3 when the means are compared using LSD. Alternate wetting and drying resulted in the lowest grain yield, while SSC (M2) recorded the highest value that was at par with continuous flooding. The results therefore suggest that maintaining rice plants at a saturated condition throughout the growing period has resulted in higher grain yield besides saving on irrigation water. It could also be observed that increase in canopy cover, number of tillers resulted in increasing photosynthetic rate under M1 and M2 treatments, thereby producing higher biomass, thousand grain weight and increase in grain yield. The lower paddy yield found under field capacity condition was mainly due to less canopy cover at booting and anthesis, less shoot dry weight and lower root length as reported by Grigg et al., (2000). 
Table.1 Influence of moisture on plant height at different growth stages in seven salt tolerant paddy genotypes

\begin{tabular}{|c|c|c|c|c|c|c|c|c|}
\hline \multirow{2}{*}{$\begin{array}{l}\text { Paddy } \\
\text { genotypes }\end{array}$} & \multicolumn{3}{|c|}{ Plant height $(\mathrm{cm})$ at 7 DAT } & \multirow[t]{2}{*}{ Mean } & \multicolumn{3}{|c|}{$\begin{array}{l}\text { Plant height (cm) at } 30 \\
\text { DAT }\end{array}$} & \multirow[t]{2}{*}{ Mean } \\
\hline & M1 & M2 & M3 & & M1 & M2 & M3 & \\
\hline V1 & 17.2 & 24.8 & 17.5 & $19.8^{b}$ & 34.6 & 39.0 & 34.7 & $36.1^{\mathrm{c}}$ \\
\hline V2 & 14.2 & 19.8 & 23.3 & $19.1^{b}$ & 36.8 & 38.0 & 36.6 & $37.1^{b c}$ \\
\hline V3 & 23.5 & 23.3 & 24.5 & $23.8^{\mathrm{a}}$ & 42.4 & 39.8 & 34.6 & $38.9^{\mathrm{bc}}$ \\
\hline V4 & 20.2 & 26.0 & 20.2 & $22.1^{b}$ & 44.8 & 48.4 & 38.9 & $44.0^{\mathrm{a}}$ \\
\hline V5 & 17.2 & 21.0 & 19.5 & $19.2^{b}$ & 42.7 & 40.3 & 39.1 & $40.7^{\mathrm{ab}}$ \\
\hline V6 & 18.7 & 27.2 & 18.0 & $21.3^{b}$ & 38.5 & 44.4 & 38.3 & $40.4^{\mathrm{abc}}$ \\
\hline V7 & 18.2 & 23.1 & 19.0 & $20.1^{b}$ & 42.7 & 42.2 & 35.5 & $40.1^{\mathrm{abc}}$ \\
\hline Mean & $18.4^{b}$ & $23.6^{\mathrm{a}}$ & $20.3^{b}$ & & $40.4^{\mathrm{a}}$ & $41.7^{a}$ & $36.8^{b}$ & \\
\hline \multicolumn{5}{|c|}{$\begin{array}{lrr}M & S E D=1.37 & C D=2.74 \\
V & S E D=2.10 & C D=4.19 \\
M V & S E D=3.63 & C D=7.25\end{array}$} & \multicolumn{4}{|c|}{$\begin{array}{lll}\text { M } & \mathrm{SED}=1.47 & \mathrm{CD}=2.94 \\
\mathrm{~V} & \mathrm{SED}=2.25 & \mathrm{CD}=4.50 \\
\mathrm{MV} & \mathrm{SED}=390 & \mathrm{CD}=7.79\end{array}$} \\
\hline
\end{tabular}

Values within each column followed by the same letter are not significantly different $(\mathrm{p}=0.05)$

Table.2 Influence of moisture on CCI at different growth stages in seven salt tolerant paddy genotypes

\begin{tabular}{|c|c|c|c|c|c|c|c|c|c|c|c|c|}
\hline \multirow{2}{*}{$\begin{array}{l}\text { Padd } \\
\text { y } \\
\text { genot } \\
\text { ypes }\end{array}$} & \multicolumn{4}{|c|}{ CCI at vegetative stage } & \multicolumn{4}{|c|}{ CCI at tillering stage } & \multicolumn{4}{|c|}{$\begin{array}{l}\text { CCI at panicle initiation } \\
\text { stage }\end{array}$} \\
\hline & M1 & M2 & M3 & $\begin{array}{c}\text { Mea } \\
\mathrm{n}\end{array}$ & M1 & M2 & M3 & $\begin{array}{c}\text { Mea } \\
\mathrm{n}\end{array}$ & M1 & M2 & M3 & Mean \\
\hline V1 & 6.72 & 4.49 & 5.19 & $\begin{array}{c}5.47^{\mathrm{c}} \\
\mathrm{d}\end{array}$ & 13.3 & 8.56 & 6.89 & $9.58^{\mathrm{d}}$ & 22.5 & 30.1 & 31.4 & $27.9^{c}$ \\
\hline V2 & 1.28 & 3.33 & 3.12 & $2.58^{\mathrm{e}}$ & 7.36 & 4.89 & 7.73 & $6.66^{\mathrm{f}}$ & 20.0 & 28.8 & 30.3 & $26.4^{\mathrm{d}}$ \\
\hline V3 & 5.74 & 6.22 & 5.02 & $\underset{c}{5.66^{b}}$ & 10.5 & 4.90 & 11.1 & $8.82^{\mathrm{e}}$ & 17.5 & 31.7 & 32.5 & $27.2^{\mathrm{d}}$ \\
\hline V4 & 7.58 & 9.54 & 10.5 & $9.21^{\mathrm{a}}$ & 16.8 & 10.9 & 12.3 & $13.3^{\mathrm{b}}$ & 30.8 & 33.7 & 34.9 & $\begin{array}{c}33.2^{\mathrm{a}} \\
\mathrm{b}\end{array}$ \\
\hline V5 & 6.89 & 6.54 & 5.37 & $6.27^{b}$ & 10.9 & 9.77 & 4.33 & $8.31^{\mathrm{e}}$ & 30.3 & 29.8 & 32.9 & $\begin{array}{c}30.9^{b} \\
c\end{array}$ \\
\hline V6 & 9.89 & 10.6 & 7.23 & $9.26^{\mathrm{a}}$ & 17.7 & 12.2 & 13.2 & $14.4^{\mathrm{a}}$ & 33.5 & 32.2 & 36.5 & $\begin{array}{c}34.1^{\mathrm{a}} \\
\mathrm{b}\end{array}$ \\
\hline V7 & 4.99 & 5.12 & 4.41 & $4.84^{\mathrm{d}}$ & 9.69 & 10.9 & 10.8 & $10.5^{c}$ & 30.4 & 36.1 & 41.4 & $35.9^{a}$ \\
\hline Mean & $6.16^{\mathrm{ab}}$ & $6.55^{\mathrm{a}}$ & $5.84^{b}$ & & $12.3^{\mathrm{a}}$ & $\underset{c}{8.87}$ & $\underset{b}{9.47}$ & & $\underset{c}{26.4}$ & $\underset{b}{31.8}$ & $\begin{array}{c}34.3 \\
\mathrm{a}\end{array}$ & \\
\hline $\begin{array}{l}\text { M } \\
\text { V } \\
\text { MV }\end{array}$ & $\begin{array}{l}\mathrm{SED}=0 . \\
\mathrm{SED}=0 . \\
\mathrm{SED}=0 .\end{array}$ & $\begin{array}{l}1 \\
3 \\
6\end{array}$ & $\begin{array}{l}D=0.43 \\
D=0.6 \\
D=1.13\end{array}$ & & $\begin{array}{ll}M & S \\
V & s \\
M V & S\end{array}$ & $\begin{array}{l}D=0 . \\
D=0 . \\
D=0 .\end{array}$ & $\begin{array}{ll}4 & \mathrm{CD} \\
7 & \mathrm{CD} \\
2 & \mathrm{CD}\end{array}$ & $\begin{array}{l}=0.49 \\
=0.74 \\
=1.28\end{array}$ & $\begin{array}{l}\text { M } \\
\text { V } \\
\text { MV } \\
4.88\end{array}$ & $\begin{array}{l}\mathrm{ED}=0 \\
\mathrm{ED}=0 \\
\mathrm{ED}=0\end{array}$ & $\begin{array}{ll}21 & \mathrm{C} \\
33 & \mathrm{C} \\
56 & \mathrm{C}\end{array}$ & $\begin{array}{l}=1.39 \\
=2.12 \\
=\end{array}$ \\
\hline
\end{tabular}

Values within each column followed by the same letter are not significantly different $(\mathrm{p}=0.05)$ 
Table.3 Influence of moisture on grain yield and zinc use efficiency in seven salt tolerant paddy genotypes

\begin{tabular}{|c|c|c|c|c|c|c|c|c|}
\hline \multirow{2}{*}{$\begin{array}{l}\text { Paddy } \\
\text { genotypes }\end{array}$} & \multicolumn{4}{|c|}{ Grain yield $\left(\mathrm{g} \mathrm{pot}^{-1}\right)$} & \multicolumn{4}{|c|}{ Zinc use efficiency } \\
\hline & M1 & M2 & M3 & Mean & M1 & M2 & M3 & Mean \\
\hline V1 & 23.1 & 21.7 & 20.0 & $21.6^{\mathrm{ab}}$ & 0.540 & 0.645 & 0.555 & $0.580^{c}$ \\
\hline V2 & 19.4 & 21.7 & 18.8 & $19.9^{b}$ & 0.440 & 0.820 & 0.475 & $0.578^{\mathrm{c}}$ \\
\hline V3 & 22.0 & 24.7 & 17.1 & $21.3^{\mathrm{ab}}$ & 0.380 & 0.805 & 0.720 & $0.635^{\mathrm{bc}}$ \\
\hline V4 & 21.3 & 23.9 & 21.8 & $22.3^{\mathrm{a}}$ & 0.465 & 0.765 & 0.685 & $0.638^{\mathrm{bc}}$ \\
\hline V5 & 17.2 & 23.5 & 19.0 & $19.9^{b}$ & 0.705 & 0.925 & 0.525 & $0.718^{\mathrm{bc}}$ \\
\hline V6 & 22.2 & 25.4 & 22.0 & $23.2 \mathrm{a}$ & 0.855 & 0.870 & 0.685 & $0.803^{b}$ \\
\hline V7 & 22.0 & 24.4 & 20.4 & $22.3 \mathrm{a}$ & 1.00 & 1.165 & 0.865 & $1.010^{\mathrm{a}}$ \\
\hline Mean & $21.0^{b}$ & $23.6^{\mathrm{a}}$ & $19.9^{c}$ & & $0.626^{b}$ & $0.856^{\mathrm{a}}$ & $0.644^{b}$ & \\
\hline $\begin{array}{ll}\text { M } & \text { SED } \\
\text { V } & \text { SED } \\
\text { MV } & \text { SED }\end{array}$ & $\begin{array}{l}\mathrm{SED}=0.72 \\
\mathrm{SED}=1.09 \\
\mathrm{SED}=1.89\end{array}$ & \multicolumn{3}{|c|}{$\begin{array}{l}C D=1.43 \\
C D=2.19 \\
C D=3.79\end{array}$} & $\begin{array}{l}\text { M } \\
\text { V } \\
\text { MV }\end{array}$ & $\begin{array}{l}D=0.07 \\
D=0.10 \\
D=0.18\end{array}$ & \multicolumn{2}{|c|}{$\begin{array}{l}C D=0.104 \\
C D=0.160 \\
C D=0.276\end{array}$} \\
\hline
\end{tabular}

Values within each column followed by the same letter are not significantly different $(p=0.05)$

Fig.1 Influence of Zinc Application on Chlorophyll Content Index at different growth stages

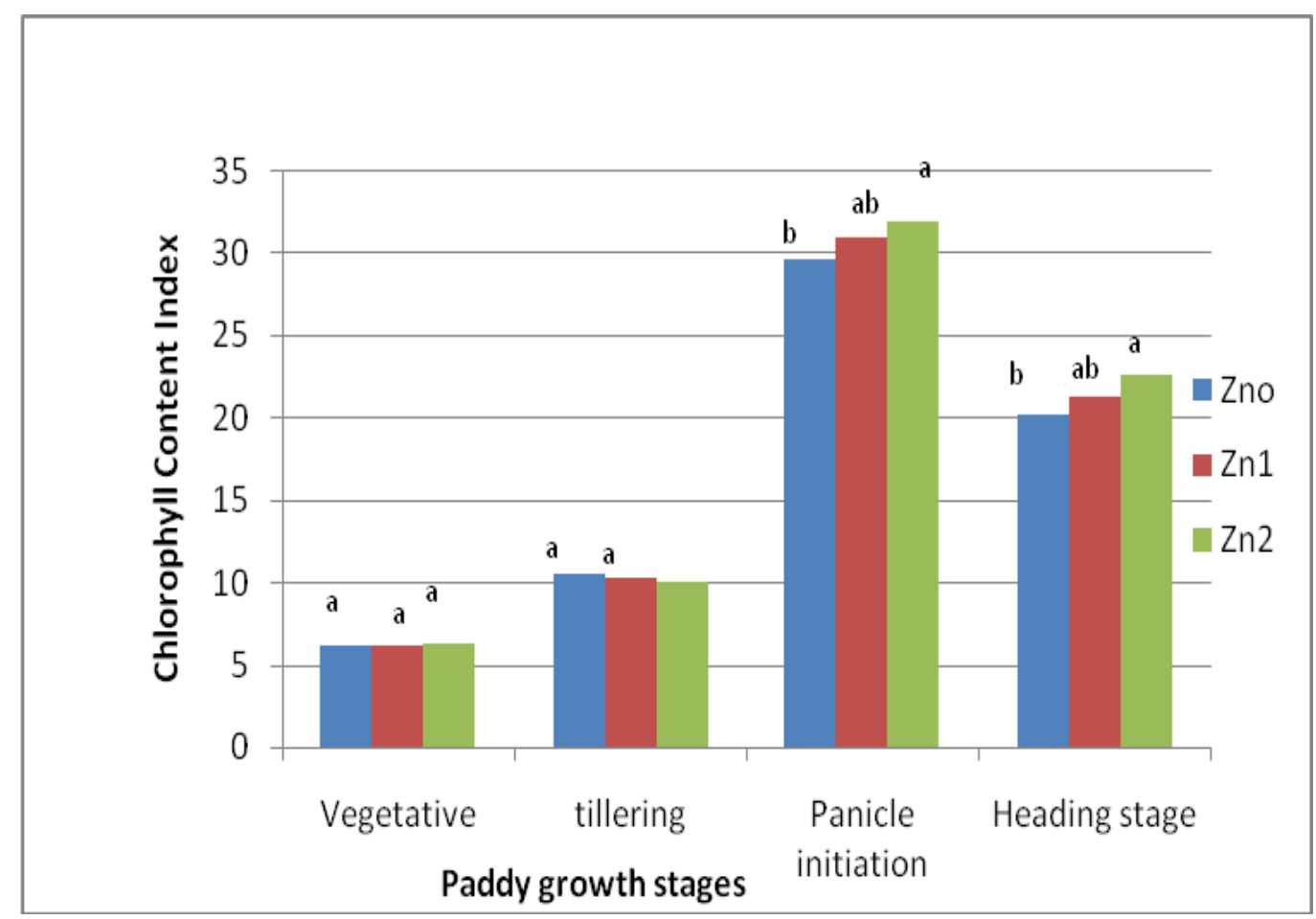


Fig.2 Plant height $(\mathrm{cm})$ and Grain yield (g pot-1) as influenced by various moisture regimes

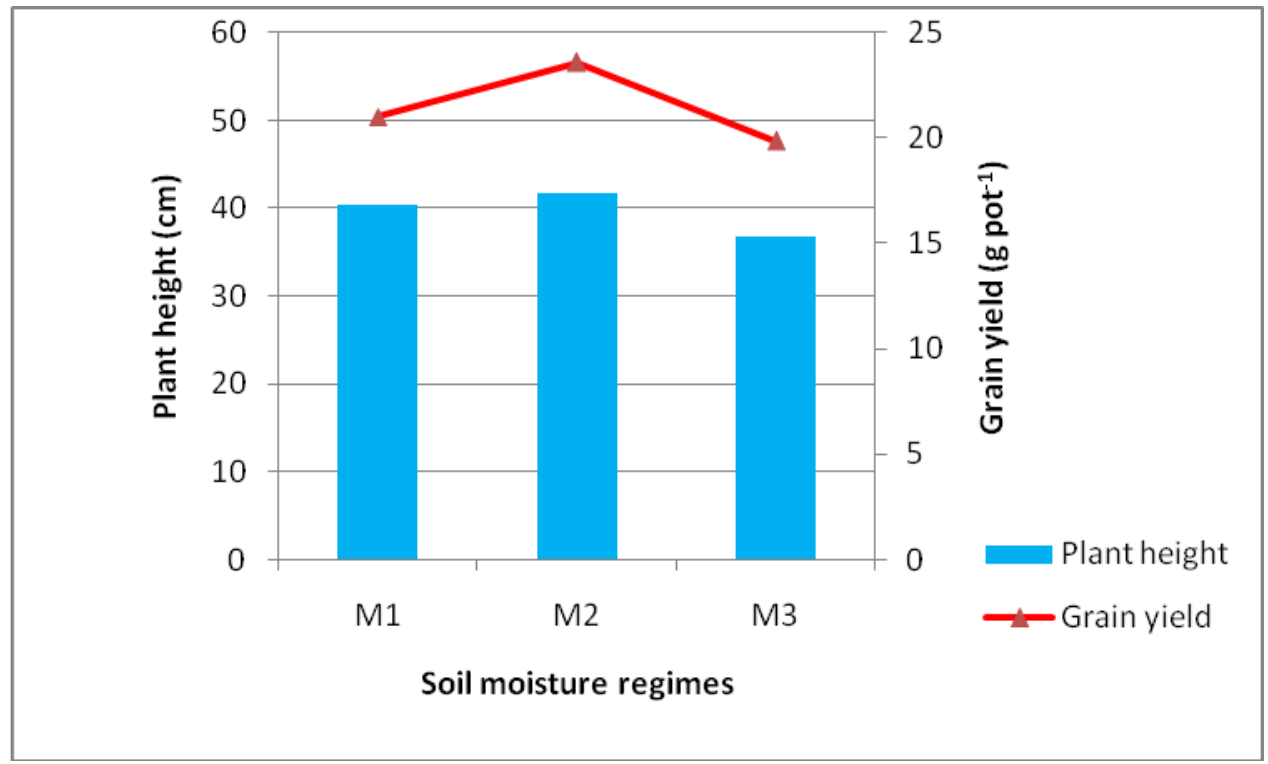

Borrell et al., (1997) and Zulkarnain et al., (2009) opined that it is not necessary to flood rice crop to obtain high grain yield and of high quality and WUE was higher in saturated soil culture than in continuous flooding cultivation.

The grain yield was significantly influenced by the moisture regimes and salt tolerant genotypes which ranged from 17.1 to $25.4 \mathrm{~g}$ pot $^{-1}$ with a mean of $21.5 \mathrm{~g} \mathrm{pot}^{-1}$. Among different salt tolerant paddy genotypes studied, TRY 1 registered the higher grain yield $\left(23.2 \mathrm{~g} \mathrm{pot}^{-1}\right)$ which was at par with TRY 3 (22.3 $\left.\mathrm{g} \mathrm{pot}^{-1}\right)$ and MTU 1010 (22.3 g pot $\left.^{-1}\right)$. The lowest grain yield was recorded in GGV 0501 and CO- 43. The SSC moisture regime significantly increased grain yield by $12.5 \%$ and $17.3 \%$ respectively as compared to those under continuous flooding (CF) and AWD regimes (Fig. 2)

\section{Zinc-Use Efficiency Index (ZnUEI)}

The zinc use efficiency index (ZnUEI) based on grain yield normally tend to increase or decrease with the moisture regime, and this effect was observed among all paddy genotypes. Three-fold differences in ZnUEI existed among the paddy genotypes $(0.38-1.2)$ across moisture regimes (Table 3) which clearly demonstrates the differential plant $\mathrm{Zn}$ demands and efficiencies for $\mathrm{Zn}$ uptake and use. The efficiency index variation was probably influenced by the differential abilities of paddy cultivar in using $\mathrm{Zn}$ for germination and growth (Baligar et al., 2001); Fageria and Baligar (2003). Rice genotypes greatly differ in their Zn efficiency; which is associated with the ability of cultivars to produce better yields under $\mathrm{Zn}$ deficient situation (Hafeez et al., 2009). The results indicate that TRY 3 was the most efficient genotype in terms of zinc use efficiency, whereas rests of the genotypes were classified as moderately efficient. None of the genotypes fell into the inefficient group. Significant interaction between moisture regimes and paddy genotypes on ZnUEI was found in the study. The efficiency index variation was probably influenced by differential paddy cultivar abilities in using $\mathrm{Zn}$ for germination and growth.

In conclusion, results of the study led us to conclude that while paddy yield significantly 
improved with zinc fertilization in zinc deficient soil, the genotype TRY 3 is the most zinc-efficient and can be recommended for cultivation in the saline Vertisols of semi-arid deccan. Field studies with this genotype can further corroborate our results. Further, saturated soil culture emerged as the best moisture conservation treatment for the performance of paddy cultivars in the region as compared to continuously flooded rice ecosystems without sacrificing rice yield.

\section{Acknowledgement}

The authors acknowledge the advisory committee members and Sh.P.Mohan Kumar who provided their valuable guidance and technical support to conduct this experiment.

\section{References}

Baligar, V.C., N. K. Fageria and He, Z. L. 2001. Nutrient use efficiency in plants. Communications in Soil Science and Plant Analysis. 32, 921-950.

Borrell, A.K., A.L Gariside and Fukai, S. 1997. Improving efficiency of water use for irrigated rice in a semi-arid tropical environment. Field Crop Res. 52, 231248.

Broadley, M.R., J. P White, J. P Hammond., I Zelko and Lux A. 2007. Zinc in plants. New Phytologist. 173, 677-702.

Cakmak, I. 2008. Enrichment of cereal grains with zinc: Agronomic or genetic biofortification? Plant and Soil, 302, 117 .

Cakmak, I., B. Torun, B. Erenoglu, L. Ozturk, H. Marschner, M. Kalayci, H. Ekiz and Yilmaz A. 1998. Morphological and physiological differences in the response of cereals to zinc deficiency. Euphytica, 100, 349-357.

Clark, R.B., 1990. Physiology of cereals for mineral nutrient uptake, use, and efficiency. In: Baligar, V.C. Duncan,
R.R. (Ed.) Crops as enhancers of nutrient use. San Diego: Academic Press., pp. 131-209.

De Datta, S.K., 1981. Principles and practices of rice production. John Wiley \& Sons, New York. 618 p.

Fageria, N. K. 2009. The use of nutrients in crop plants. CRC Press, Boca Raton, Fl

Fageria, N. K., and Baligar, V. C. 2003. Methodology for evaluation of lowland rice genotypes for nitrogen use efficiency. Journal of Plant Nutrition. 26, 1315-1333.

Frossard, EM., F. Bucher, A. Mozafar and Hurrell R. 2000. Potential for increasing the content and bioavailability of $\mathrm{Fe}, \mathrm{Zn}$ and $\mathrm{Ca}$ in plants of human nutrition. Journal of the Science of Food and Agriculture. 80, 861-879.

Graham RD. 1984.Breeding for nutritional characteristics in cereals. In: Tinker PB, Lauchli A (Ed.). Advances in plant nutrition, Praeger Publishers, New York., 57-102.

Graham, R.D., J.S. Ascher and Hynes, S.C. 1992.Selecting zinc efficient cereal genotypes for soils of low zinc status. Plant and Soil. 146, 241-250.

Grigg, B.C., C.A. Beyrouty, R.J. Norman, E.E.Gbur, M.G. Hansn, and Wells B.R. 2000.Rice responses to changes in flood water and $\mathrm{N}$ timing in southern USA. Field Crop Res. 66, 73-79.

Hafeez, B., Y.M. Khanif, A.W. Samsuri, O. Radziah, Saleem M.2009. Zinc status of Kelantan state. In: 'Proceeding of Soils 2009 on Soil health: Preserving resources for sustainable Agriculture from 13-15 April, 2009 at Terengganu', pp. 290-293. (Malaysian Society of Soil Science).

Hambidge, M., 2000. Human zinc deficiency. jJournal of Nutrition. 130, 1344-1349.

Horton, S., H. Alderman and Rivera, J.A. 2009. Hunger and malnutrition. In: Lomborg, B. (Ed.) Haung DF,XI LL, 
wang ZQ, Liu, LJ,yang JC.2008. effects of irrigation regimes during grain filling on grain quality and the concentration and distribution of cadmium in different organs of Rice. Acta Agronomica Sinica. 34:456-464.

Global crisis, global solutions. Cambridge University Press, New York., pp. 305354.

Khairi, M., M. Nozulaidi, A. Afifah and. Jahan M.S 2015. Effect of various water regimes on rice production in lowland irrigation. Aus. J. Crop Sci. 9(2): 153159.

Lindsay, W., 1972. Zinc in soil and plant nutrition. Adv. Agron. 24, 147-188.

Mikkelsen, D.S., and Shiou, K. 1977. Zinc fertilization and behaviour in flooded soils. Spec. Publ. No. 5 Comm. Agric. Bur., Farnham Royal.

Panse, V.G., and Sukhatme, P.V. 1985. Statistical methods for agricultural workers. ICAR Publications. New Delhi.

Sajwan, KS., and Lindsay, W.L. 1988. Effect of redox, zinc fertilization and incubation time on DTPA-extractable zinc, iron and manganese. Commun. Soil Sci. Plant Anal. 19, 1-11.

San, Z.F., 2006. Trace elements and human health. Stud Trace Elem Health. 23(3):66-67

Sillanpaa, M.1982.Micronutrients and nutrient status soils: a global study. Rome: FAO, 1. 444p. (Soils Bulletin, 48).

Singh M V. 2009. Micronutrient nutritional problems in soils of India and improvement for human and animal health. Indian Journal of Fertilizers. 5, 11-26.

Von Braun J., M.W. Rosegrant, R.PandyaLorch, M.J.Cohen, S.A.Cline, M.A. Brown and Bos M.S. 2005. New risks and opportunities for food security: scenario analysis for 2015 and 2050 . 2020. Discussion Paper No.39. International Food Policy Research Institute (IFPRI), Washington, D.C., 140.

Walker, C.L.F., M. Ezzati and Black, R.E. 2009. Global and regional child mortality and burden of disease attributable to zinc deficiency. European Journal of Clinical Nutrition. 63, 591-597.

Welch, R.M. 1993. Zinc concentrations and forms in plants for humans and animals. In: Robson, A.D. (Ed.) Zinc in soil and plants. Dordrecht: Kluwer Academic Publishers, pp.183-195.

Zeigler, R.S., S.A. Leong and P.S.Teng.1994.Rice blast disease. IRRI, Manila Philippines, pp. 7-10

Zhang, H., Y. Xue, Z. Wang, J Yang and Zhang, J. 2009. An alternate wetting and moderate soil drying regime improves root and shoot growth in rice. Crop Sci., 49, 2246-2260.

Zulkarnain, W.M., M.R. Ismail, M Ashrafuzzaman, H.M. Saud and I.C. Haroun. 2009. Rice growth and yield under rain shelter house as influenced by different water regimes. Int. J. Agric. Biol., 11, 566-570.

\section{How to cite this article:}

Prabhavathi, M., Hrittick Biswas and Chandra Sekharan, N. 2019. Screening of Paddy (Oryza sativa L.) Genotypes for Zinc Efficiency under Different Moisture and Salt Stress Condition in Semi-Arid Vertisols. Int.J.Curr.Microbiol.App.Sci. 8(03): 1514-1522.

doi: https://doi.org/10.20546/ijcmas.2019.803.175 